\title{
Circulation of biogenic substances in the Kamionka river-lake system
}

\author{
Wojciech Maślanka, Jerzy Jańczak \\ University of Gdańsk, Institute of Geography, Department of Lakelands Geography, Bażyńskiego 4, 80-952 Gdańsk, Poland, \\ e-mail: bgiowm@univ.gda.pl
}

\begin{abstract}
Reservoirs in river-lake systems play a dominant role in the circulation of biogenic substances. Their evolutional transformations, consisting in accumulation of substances, results it their ultimate disappearance. However, at a given moment, the roles played by reservoirs are far more diverse - they accumulate, perform a transit role or supply the system with biogenic substances. The assignment of roles played in the system to reservoirs performed on the basis of data of 2006 was verified in 2007 with respect to the durability of their roles. Some of the lakes consistently accumulated biogenic substances. Their performing of this function in the system was facilitated by favourable morphometric conditions accompanied by strong pressure, exceeding the value determined for critical load. A tendency of supplying the system by other lakes was visible when they were charged with a lower load than the critical values for phosphorus load. The reservoirs then utilised the opportunity to discharge a part of biogenic substance present in them, partially of internal origin.
\end{abstract}

Key words: biogenic substances, river-lake system, Kashubian Lakeland

\section{Introduction}

The process of circulation of biogenic substances in a vast majority of river-lake systems of the area of lakelands has not been investigated so far. There are few systems in which the issue was the subject of proper research (e.g. Bajkiewicz-Grabowska 2002; Hillbricht-Ilkowska 1994). In the area of the Kashubian Lakeland the circulation of biogenic substances was analysed, among others, on the example of the Struga Siedmiu Jezior, investigated in 2000 (Bajkiewicz-Grabowska and Zdanowski 2006) and the Kamionka, Mielnica and Radunia investigated in 2006 (Jańczak et al. 2007). The research drew attention to a special role played by lakes in systems. Their individual predispositions had a modifying influence on the character of the circulation of biogenic substances. In order to determine the durability of the course of the quantitative changes of biogenic substances in the system observed in 2006, the research was continued in the catchment of the River Kamionka also in 2007.

Like in 2006, in chosen profiles of the Kamionka river-lake system, monthly observations of the val- ue of discharge were performed with water sampling. They were used, after determination of concentrations of total phosphorus and nitrogen, to determine the value of the load of biogenic substances. Measurement sites were located on outflows from the lakes of the system and in mouths of bigger tributaries (Fig. 1). Areas of the catchment not covered by the control of the value of the supplied load of biogenic substances constituted maximally $17 \%$ of the whole alimentation area of the lakes of the system (Lake Sobąckie), usually less than $10 \%$ of their total area. In order to evaluate the role of particular reservoirs in the system (Table 1), the total supply of biogenic substances was increased by an estimated value of load from the area of the catchment not covered by measurements (Giercuszkiewicz-Bajtlik 1999).

\section{Results and discussion}

The diverse impact, in 2006 and 2007, of the set of factors influencing the character of processes of transformation of biogenic substances in the Kamionka river-lake system was reflected in the recorded 
Table 1. Basic data concerning analysed lakes and their catchments

\begin{tabular}{|c|c|c|c|c|c|c|c|}
\hline \multirow{2}{*}{ No. } & \multirow{2}{*}{ Lake } & \multirow{2}{*}{$\begin{array}{l}\text { Area } \\
\text { (ha) }\end{array}$} & \multicolumn{2}{|c|}{ Depth (m) } & \multirow{2}{*}{$\begin{array}{l}\text { Volume } \\
\left(\text { dam }^{3}\right)\end{array}$} & \multirow{2}{*}{$\begin{array}{l}\text { Development of } \\
\text { shoreline }\left(\mathrm{m} \mathrm{ha}^{-1}\right)\end{array}$} & \multirow{2}{*}{$\begin{array}{l}\text { Catchment area } \\
\qquad\left(\mathrm{km}^{2}\right)\end{array}$} \\
\hline & & & maximum & mean & & & \\
\hline 1 & Wierzchołek & 17.3 & 3.1 & 1.8 & 303.7 & 117 & 26.48 \\
\hline 2 & Średnik & 19.3 & 12.5 & 4.0 & 770.2 & 96 & 35.43 \\
\hline 3 & Gatno & 72.6 & 25.2 & 10.5 & 7598.8 & 42 & 37.87 \\
\hline 4 & Hutowe & 105.2 & 16.9 & 6.5 & 6892.5 & 84 & 44.22 \\
\hline 5 & Sobąckie & 91.1 & 28.4 & 11.0 & 10010.6 & 84 & 83.96 \\
\hline 6 & Polaszkowskie & 106.5 & 10.0 & 4.2 & 4491.0 & 77 & 96.91 \\
\hline
\end{tabular}

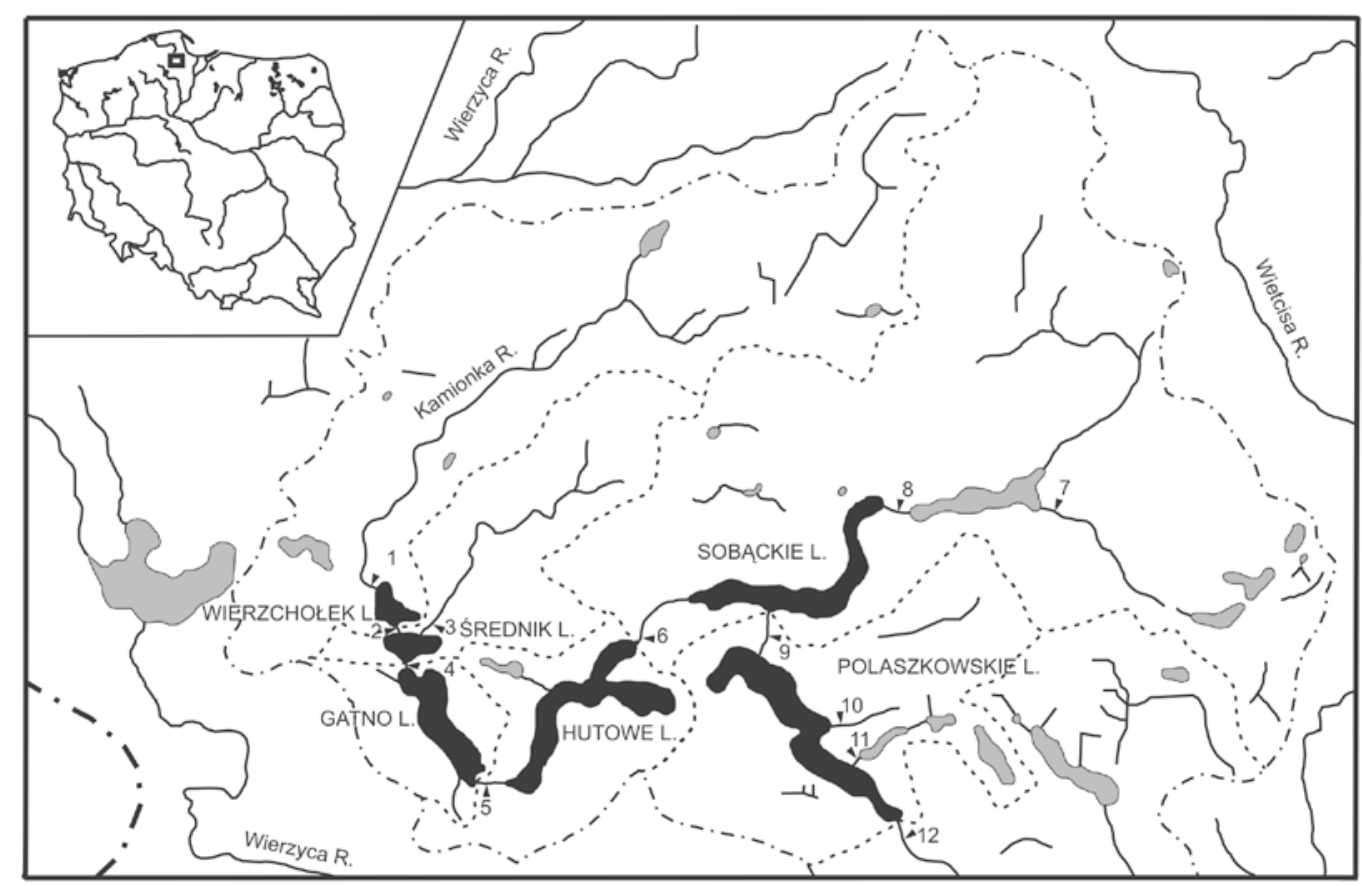

Fig. 1. Distribution of analysed lakes in the Kamionka river-lake system

annual values of loads. Annual values recorded in 12 research profiles were characterised by a lack of tendency of an analogous increase or decrease in the value of loads in a given year (Fig. 2 and 3). Sometimes, the direction of change was different in the case of $\mathrm{P}$ and $\mathrm{N}$ loads - e.g. the outflow of Lake Wierzchołek in 2007 was characterised, in comparison with 2006, by a reduction of phosphorus load by $42 \%$ and an increase in nitrogen load by $28 \%$. In the majority of research profiles, however, the tendency of changes for both main biogenic substances was analogous (Figs 2 and 3 ), though sometimes on a diverse scale (e.g. tributary to Lake Gatno - measurement site 4). In the side tributaries to the Kamionka, different tendencies in the direction of changes between the value of phosphorus and nitrogen loads were not observed.
The presence of numerous lakes in the system modified the circulation of biogenic substances. The values of loads recorded at outflows from lakes did not always increase with an increase in catchment area (Figs 4 and 5). A reduction in load was recorded in 2006 on outflows from Lake Średnik and Lake Hutowe (annual load of total phosphorus), while in 2007 on the outflow from Lake Gatno and lake Polaszkowskie (total phosphorus and nitrogen). A considerable increase in load in the system is observed only on the outflow from Lake Hutowe (in the case of nitrogen load) and Lake Sobąckie (phosphorus). Lake Polaszkowskie, closing the observed fragment of the system, plays a variable role. In 2006 it was characterised by an increase in the value of nitrogen and phosphorus load, while in 2007, a decrease in their load was observed. 


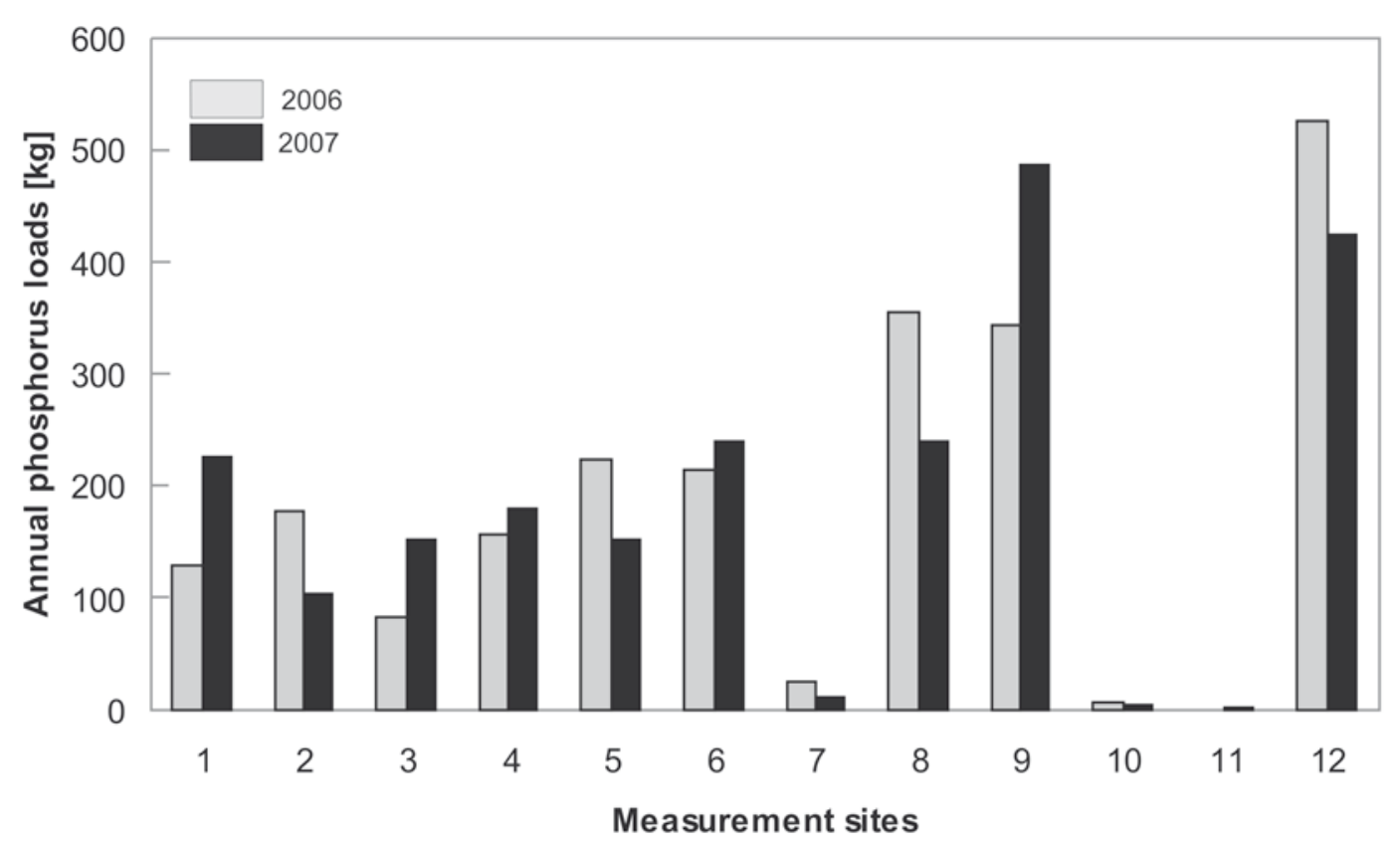

Fig. 2. Annual phosphorus loads from controlled catchments in the Kamionka river-lake system in 2006 and 2007

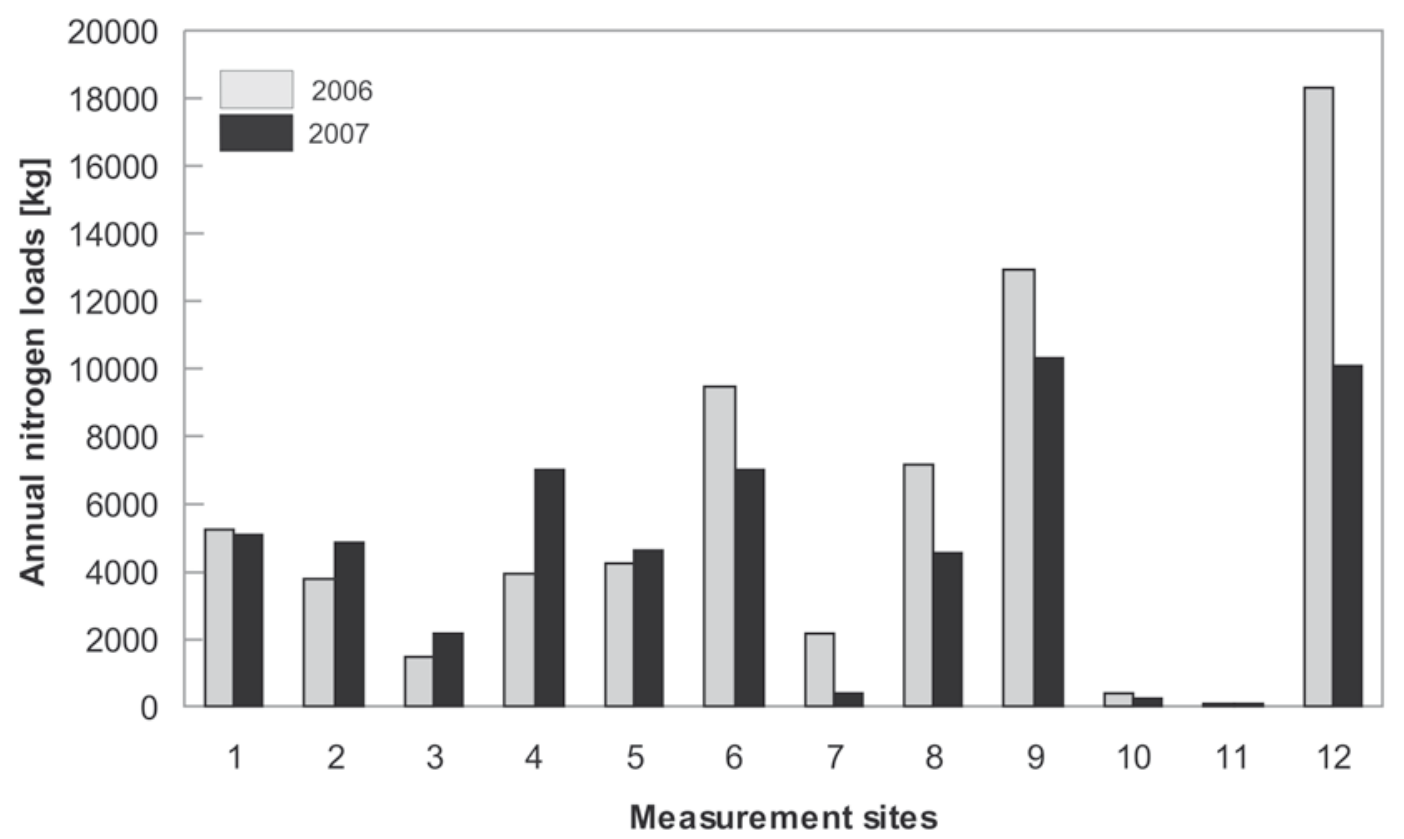

Fig. 3. Annual nitrogen loads from controlled catchments in the Kamionka river-lake system in 2006 and 2007 


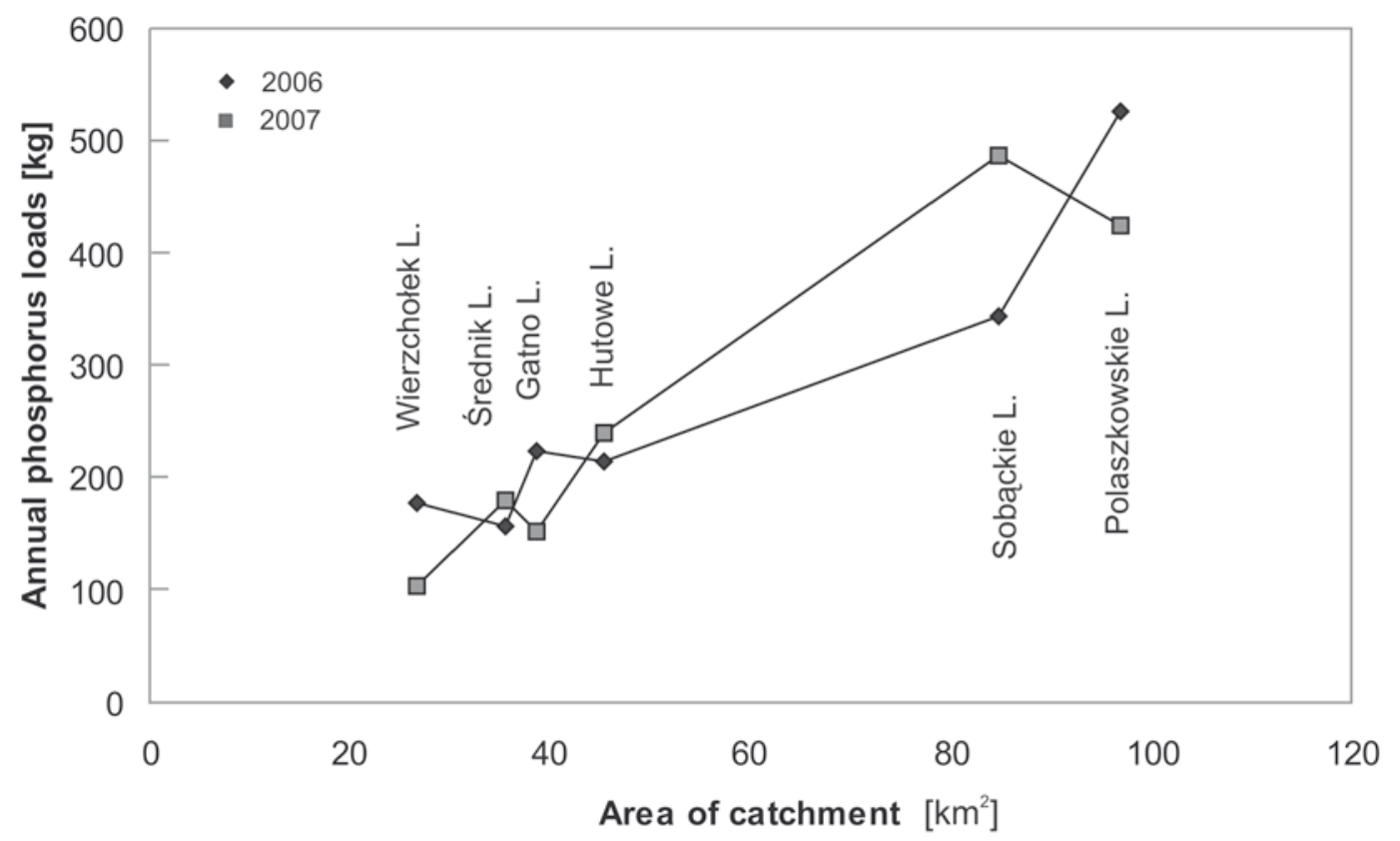

Fig. 4. Annual phosphorus loads recorded on outflows from lakes in the Kamionka river-lake system in 2006 and 2007

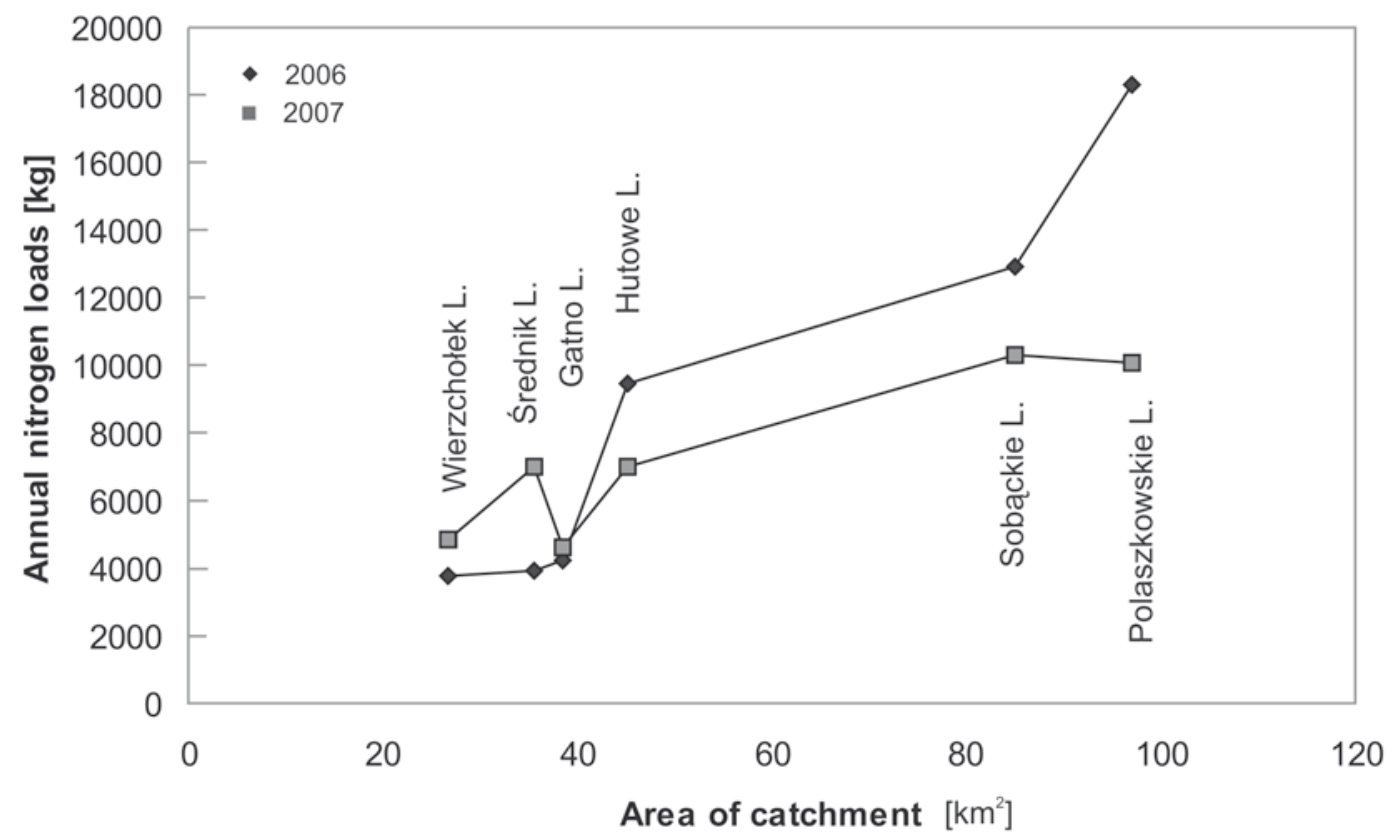

Fig. 5. Annual nitrogen loads recorded on outflows from lakes in the Kamionka river-lake system in 2006 and 2007 
The role played by lakes in a river-lake system is clearly reflected in the relationship between the value of the load of biogenic substances supplying and leaving reservoirs. Lake Wierzchołek, generating an increase in the value of phosphorus load in the system in 2006 against the load reaching it (Fig. 6), in 2007 accumulated phosphorus loads - of the $248 \mathrm{~kg}$ supplying the reservoir only $104 \mathrm{~kg}$ reached Lake Średnik situated below. Lakes Srednik and Sobąckie in both years, though to a different degree, accumulated phosphorus load (Fig. 6). The role of lakes Gatno, Hutowe and Polaszkowskie in the process of the circulation of biogenic substances was variable. In 2006 lakes Gatno and Polaszkowskie supplied the system with phosphorus, while in Lake Hutowe the supplied load was reduced. The situation changed in 2007: lakes Gatno and Polaszkowskie accumulated, while Lake Hutowe increased the load of total phosphorus in the system. In the case of nitrogen transport, the role of the reservoirs was more stable. Exceptions included Lake Gatno: in 2006 slightly enriched the river-lake system, and in 2007 considerably reduced the value of the load, and Lake Polaszkowskie, which strongly supplied the system with nitrogen in 2006 and slightly accumulated it in 2007. The remaining lakes were characterised by stable roles in circulation of matter in the system (Fig. 7).
The actual roles of particular lakes in the circulation of biogenic substances depends, apart from stable morphometric features, on numerous variable factors (Uchmański and Szeligiewicz 1988). Especially noteworthy is the influence on the supply and transformation of biogenic substances of hydrological and meteorological conditions. As a result of their variability, some lakes can perform different functions in 2006 and 2007 in the circulation of biogenic substances in the Kamionka river-lake system.

The actual values of loads exerting pressure on lakes, variable annually, in most of the analysed reservoirs exceed the values of critical loads (Table 2). In the case of lakes Wierzchołek and Średnik they are several times higher. This is related both with the values of the index of proper catchment of over 150, as well as with high values of unit loads, characteristic of the catchments of their tributaries. In the case of the remaining lakes, the ratio of the size of their alimentation areas to their area takes more favourable values.

Lake Wierzchołek is not a stable accumulator of the phosphorus load reaching it. Unlike in 2007, in 2006 it enriched the river-lake system in phosphorus. In the case of nitrogen, in both years there was a small reduction of the load reaching it on the surface. Despite the considerable values of loads reaching Lake Średnik, it invariably accumulates phosphorus and ni-

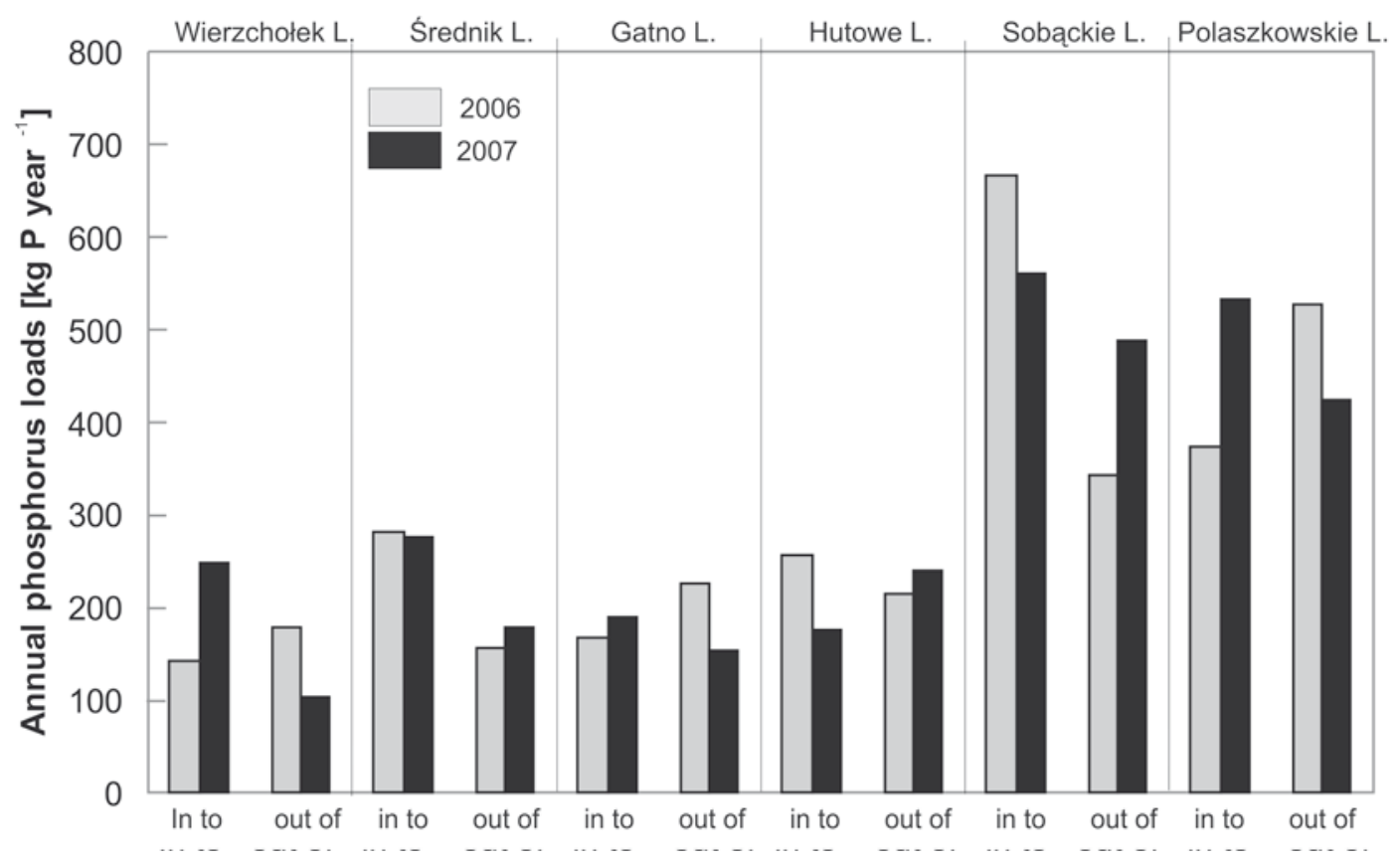

Fig. 6. Total phosphorus load reaching and leaving on surface the lakes of the Kamionka river-lake system in 2006 and 2007 


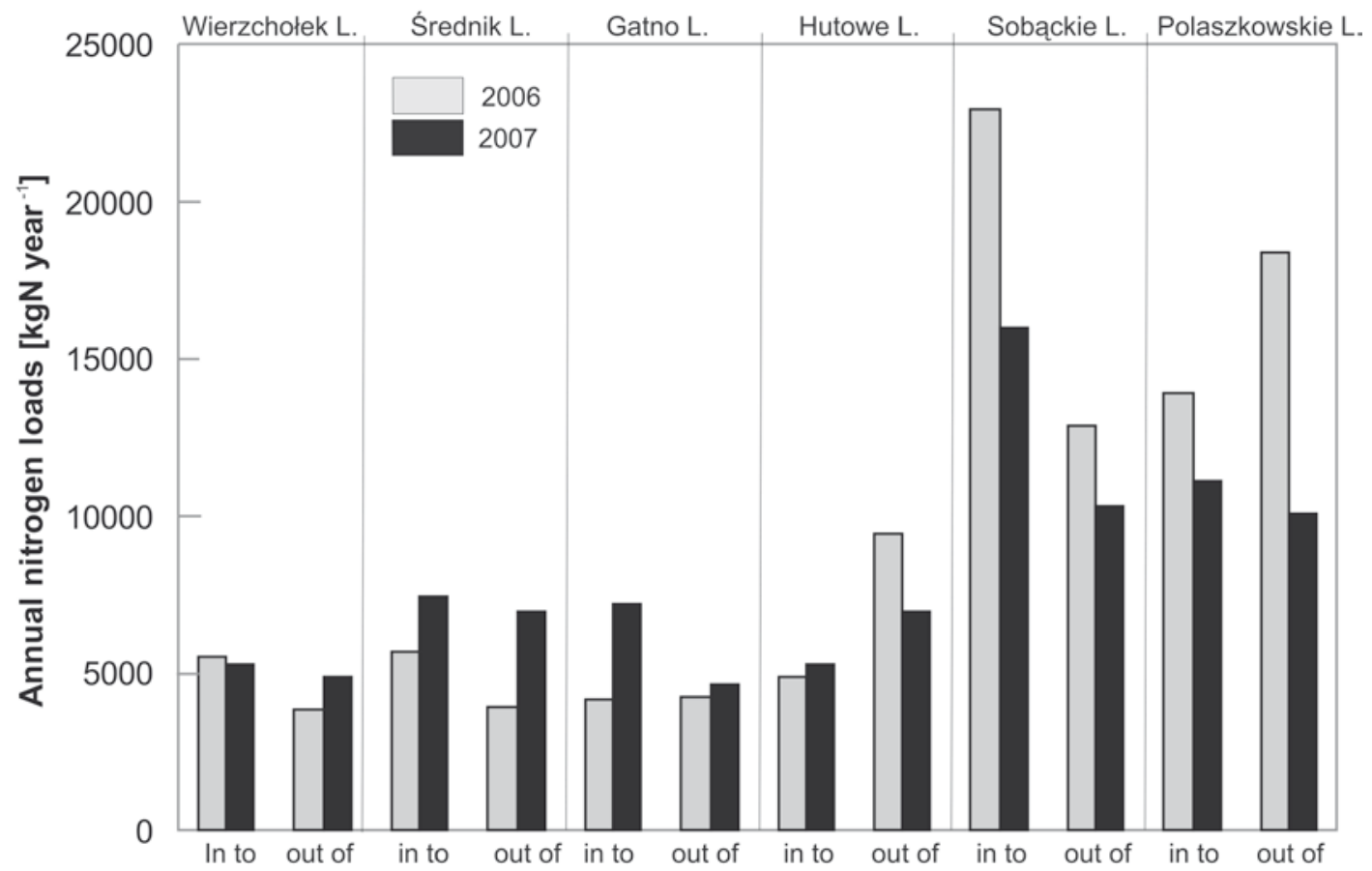

Fig. 7. Total nitrogen load reaching and leaving on surface the lakes of the Kamionka river-lake system in 2006 and 2007

trogen. Better morphometric parameters seem to be favourable for accumulation in it of a part of the heavy loads reaching it additionally also by side tributary to the lake. It discharges an exceptionally high unit load, over 2 times higher than that typical of the Kamionka catchment. Such a clear role in the system is also played only by Lake Sobąckie, consistently reducing the value of the load of biogenic substances in the system though its side tributary from Lake Linowskie is also characterised by higher unit loads. The roles of the remaining reservoirs appear to be variable: Lake Hutowe usually supplies (except for phosphorus load in 2006), while lakes Gatno and Polaszkowskie consistently supplied in 2006, and deposited the load of biogenic substances in 2007 (Figs 4 and 5).

Lakes Średnik and Sobąckie, reducing the quantity of biogenic substances in the system, were characterised in both years, though on a different scale, by values of actual phosphorus loads higher than the critical ones. In the case of the remaining lakes, in the years when they accumulated phosphorus, a higher absolute charge with the load was observed in them. Except for Lake Wierzchołek, characterised by an extreme disproportion between actual and critical loads, these were years when the value of the load reaching the reservoir exceeded the critical value. In years with a smaller phosphorus supply - below the critical load - lakes enriched the system in phosphorus, drawing on the internal load.

\section{Conclusion}

The dominant role in the transformation of the circulation of biogenic substances in river-lake systems is played by lakes. The diverse system of lakes enabled studying the impact of particular reservoirs on the transformation process of loads of different values. The two-year observation period also enabled determining the durability of the roles of particular lakes in the process of matter circulation. The studies existing so far, sometimes ascribed a certain role to reservoirs on the basis of annual (e.g. Jańczak et al. 2007) or expedition research (e.g. Bajkiewicz-Grabowska and Zdanowski 2006). The research results show that in such a short time it is not possible to definitely determine the type a given lake represents - if it accumulates, plays a transit role or enriches the river-lake system in biogenic substances.

The stability of an accumulating role in the system observed in the case of some reservoirs seems to 
be related on the one hand to appropriate morphometric conditions, enabling accumulation of excess loads, and on the other hand to the presence of a considerable pressure exceeding the value of critical load. The influence of morphometry on the role of reservoirs in the system is manifested by shallow Lake Wierzchołek, which despite considerable pressure does not reveal stability in accumulation of a part of phosphorus load reaching it.

There is a considerable difficulty in determining the participation of internal sources in supplying lakes with biogenic substances. However, the participation is clear in the value of the load leaving lakes of a riverlake system. It becomes visible in the case of surface supply to lakes lower than the estimated critical values. Then the lake seems to utilise the opportunity to remove a part of accumulated biogenic substances from its basin when smaller pressure is exerted on it.

\section{References}

Bajkiewicz-Grabowska E., 2002, Obieg materii w systemach rzeczno-jeziornych (Circulation of matter in the riverlake systems), Wyd. UW, Warszawa, p. 274 (in Polish, English summary).
Bajkiewicz-Grabowska E., Zdanowski B., 2006, Phosphorus retention in lake sections of Struga Siedmiu Jezior, Limnol. Rev. 6: 5-12.

Giercuszkiewicz-Bajtlik M, 1990, Prognozowanie zmian jakości wód stojących (Predicting of quality changes in stagnant waters), Wyd. IOŚ, Warszawa, p.74 (in Polish).

Hillbricht-Ilkowska A., 1994, Ocena ładunku fosforu i stanu zagrożenia jezior Suwalskiego Parku Krajobrazowego oraz niektóre zależności pomiędzy ładunkiem a wskaźnikiem trofii jezior (Evaluation of the phosphorus load, and degree of endangerment, of lakes in Suwałki Landscape Park, and some relationships between the load and the indices of the trophic status of lakes), Zesz. Nauk. Kom. „Człowiek i Środowisko” PAN 7: 201-214 (in Polish, English summary).

Jańczak J., 1997, Atlas jezior Polski. T. 2. (Atlas of Polish lakes. Vol. 2.) Bogucki Wyd. Nauk., Poznań, p.256 (in Polish).

Jańczak J., Maślanka W., Nowiński K., 2007, The impact of selected Pomeranian lakes on nutrient load transformation, Limnol. Rev. 7(4): 191-197.

Uchmański J., Szeligiewicz W., 1988, Empirical models for prediction water quality applied to the data on lakes of Poland, Ekol. Pol. 36: 285-316.

Vollenweider R. A., 1976, Advances in defining critical loading levels phosphorus in lake eutrophication, Mem. Inst. Ital. Idrobiol. 33: 53-83. 